\title{
Evaluation of the therapeutic effect of Some Herbal and foods ON TUBERCULOSIS PATIENTS
}

\author{
By \\ EL- Zainy, A.R.M. \\ Department of Home Economics - \\ Faculty of Specific Education - \\ Mansoura University - Egypt \\ Mona Y. A. Mostafa \\ Department of Home Economics - \\ Faculty of Specific Education - \\ Mansoura University - Egypt

\section{EL-Shekety, F.M.M.} \\ Department of Home Economics - \\ Faculty of Specific Education - \\ Mansoura University - Egypt
}

\section{Research Gournal Specific Fducation}

Faculty of Specific Fducation

Mansoura University

ISSUE NO. 54, APRIL. 2019

مجلة بحوث التربية النوعية - جامعة المنصورة

العدد الرابع والخمسون - أبريل - 19. 


\title{
Evaluation of the therapeutic effect of Some Herbal and foods ON TUBERCULOSIS PATIENTS
}

\author{
EL- Zainy, A.R.M., Mona Y. A. Mostafa and EL-Shekety, F.M.M.*
}

\section{Abstract}

This study was conducted to determine the effect of treatment of certain foods and herbs in treatment and improving the health status of tuberculosis patients. The study was conducted on 60 patients in Mansoura Chest Hospital - Dakahlia governorate of both sexes (48 males, 12 famales) aged 18-60 years. Some physicall measurements of weight, length and clinical examinations were conducted by hospital doctors. Some laboratory tests were carried out on blood samples of the patients to identify the proportion of hemoglobin and hematocrit. Also the sputum samples were taken to estimate the extent of tuberculosis incidence. Patients were divided into four equal groups (15 patients each) as follows: group1 (positive control group) fed on hospital meal only. Group 2 was fed on the hospital meal in addition to the herbal mixture drink (echinace, juniper, honeysuckle and horehound) 3 times daily. Group 3 was fed on the hospital meal in addition to the mixture of liquid consisting of honey bee, grounded yellow fenugreek, peanut and goat's milk 3 times aday. Group 4 was fed on both the mix of herbs and the liquid mixture. All the four groups continued on the hospital drugs beside food treatments over the period of the experiment ( 3 months). The herbs mixture and liquid mixture were subjected to sensory evaluation and chemical analysis to identify their contents of protein, fiber, ash, moisture and fat. All the mentioned tests were run during the frist and second months of the experiment and at the end of the trial period (3 months). The combination of herbs showed the best results in the elimination of the tuberculosis bacteria. Meanwhile, the liquid mixture recorded the best results in improving hemoglobin and hematocrit and increasing the weight of normal TB patients. Basedon the results, mixed

* Department of Home Economics - Faculty of Specific Education - Mansoura University Egypt. 
herbs and liquid mixture can be used together side by side with hospital medicines to improve the patients' health status in a short period of time.

Key words: Tuberculosis, Juniper, Horehound, Echinacea, Sputum examination, Peanut, Fenugreek, Hemoglobin, Hematocrit, Therapeutic effect.

\section{INTRODUCTION}

Tuberculosis (TB) is a disease, which is caused by the bacterium tuberculosis. It was reported that around $10 \%$ of the latest infections happens to active disease that, if it isn't treated, it can destroy around fifty percent of the infected people. There are some usual symptoms of active TB such as chronic cough with fever, bloody sputum, weight loss, and night sweats (Konstantinos, 2010). Patients with tuberculosis have some symptoms as appetite reduction, micronutrient malabsorption, and altered metabolism which leads to wasting. Patients with malnourished tuberculosis have postponed recovery and higher levels of mortality than the wellnourished patients. Designated that there is a link between tuberculosis and both malnutrition and overcrowding; that makes it one of the most dominant diseases over the poor (Hossain et al., 2010). The most affected ones by tuberculosis are the poorest people from the poorest countries. They are not only exposed to the disease because of their living and working conditions, but they are also plunged deeply into poverty as a consequence of TB (Halezeroğlu and Okur, 2014).

Honeysuckle is used as a treatment for inflammation, swelling, colds, fever, sores, boils, viral and bacterial infections. Nowadays, this honeysuckle is considered as a proven antibiotic. It is a considered as a broad-spectrum antibiotic for bacteria (Jin et al., 2006). Horehound can be used as a cure for symptoms that are inflammatory-related as fever, flue and sore throat. It is used for respiratory problems like cough and asthma (Pukalskas et al., 2012). Echinacea`s role is to confirm immune system function to lighten the flu period and severity. It has many physiological properties among which are; the stimulation of phagocy-tosis, cytokine production, and anti-inflammatory function (Perry et al., 2002). Juniper 
used for dyspepsia, it has digestive, stomachic, and antirheumatic functions. Because of these antiseptic functions it is used as an antimicrobial activity of the essential juniper against some bacteria (Angionl et al., 2003).

Fenugreek is recognized to have many pharma-cological functions such as hypoglycemia gastroprotective, hypocholesterolemia, chemopreventive, anti- oxidant anti-in ammatory, antipyretic, laxative and appetite attributes (Basch $\boldsymbol{e t}$ al., 2003). Goat's milk should be used regularly by people, who have problems with malabsorption issues, osteoporosis, anemia, or prolonged treatments also with iron supplements (Angelis et al., 2006). Honey as a therapy can be used for wound healing, cough, sore throat, topical antisepsis, laxative action, prevention and treatment of scars. Most microorganisms do not grow in honey, so sealed honey does not spoil, even after thousands of years (Chen et al., 2000).

Aim of the study: This study aims to speed healing of tuberculosis and eliminate the bacteria that causes it, using some herbs and foods with therapeutic effect on the disease.

\section{Material and Methods:}

Materials: The raw materials: Honey white (ISIS Co, Egypt), goat milk (Nestle Egypt), peanut and fenugreek were purchased from local market of different areas in Mansoura city Egypte. Echinace (Echinacea purpurea), honeysuckle (Lonicera spp), hore hound (Marrubium vulgar/) and juniper (Juniperus communis L, cupressaceae), were obtained from the National Research Center, Giza, Egypt.

Patients: Experiments were conducted on 60 tuberculosis patients of both sexes (48 male and 12 female) aged 18:60 years reserved at Mansoura Chest Hospital.

\section{Methods}

Preparation of raw materials: Echinace, honeysuckle, horehound and juniper were grinded well until become soft powder then sieued. Peanuts were crushed and grinded, fenugreek was grinded, goat milk was mixed and filterd then pasteurized at $75 c$ for five minutes. . Preparation of herbal mix: The mixture contains four herbs: (echinace, juniper, 
honeysuckle and horehound). It was mixed in to soft powder and then wrapped in paketas containing each baguette on $4 \mathrm{~g}$ of herbs in equal proportions $1 \mathrm{~g}$ per herb. They were kept in plastic bags in a dry and cool atmosphere for use. Herbs were saved in coldness, dryness and darkness to protect them from oxidation. The herbal mixture was soaked in a cup (200 $m l)$ of boiling water for 10 minutes before drinking.

Preparation of liquid mixture: The liquid mixture contains (honey bee, grounded yellow fenugreek, peanut and goat's milk) was prepared as follow; $5 \mathrm{~g}$ crushed peanuts and $10 \mathrm{~g}$ grounded fenugreek mixed with $20 \mathrm{~g}$ honey then added to cup $(200 \mathrm{ml})$ of (boiled goat's milk and boiled water).

Body measurements:

Body weight: weight was measured using beam balance. The TB patients were weighed to the nearest kilogram without shoes and in light clothes the scales were calibrtated befor use (Cai et al ., 2004) .

Height (HT): The height was measured using a meter while the TB patient was in the standing position with no shoes and was recorded to the nearest centimeter (diehl, 2003).

\section{Body Mass Index(BMI) :}

Was calculated:

$\mathrm{BMI}=\mathrm{Wt}(\mathrm{kg}) /($ Height meter $) 2$

The grades of obesity utilizing the BMI:

Underweight $<20 \mathrm{~kg} / \mathrm{m} 2$

Desirable range of BMI(normal) $20-<25 \mathrm{~kg} / \mathrm{m} 2$

Over weight $=>25=30 \mathrm{~kg} / \mathrm{m} 2$.

Obesity $=>30 \mathrm{~kg} / \mathrm{m} 2$ (diehl,1991).

\section{product analytical methods:}

Sensory evaluation: The bitterness value of all absinthes was defined by applying the procedure used in the European pharmacopoeia. In many researches the value of bitterness was handled as copmlementary of the dilution,which has already been tasted as bitter. That was defined by comparing it with quinine hydrochloride. In result of this comparison it was 
found that the bitterness value was at 200,000. As it was set a taste panel, trained by five people. Furthermore the value of bitterness was calculated as average for all panel members. Additionally the taste panel qualitatively examined the absinthes to find the traditional wormwood aroma and the louche effect (Stalikas, 2007).

Chemical analysis: In particular and according to the mentioned standard levels, the final chemical analysis of ash, total crude and protein were done. Additionally, it was used a nitrogen to protein conversion factor of 6.25 per gram of sample to calculate the level of protein (Wursch et al., 1984).

Total phenol content: TPC_ Total phenol content in each extract was defined by using the FC with simple updates. In the first the freezedried extract was melted naturally in distilled water in a concentration of 50 $\mu g / m L$. After that the calibration curve was done by gallic acid (0-60 $\mu \mathrm{g} / \mathrm{mL})$. The next step is putting the diluted extract or gallic acid $(1.6 \mathrm{~mL})$ $0.2 \mathrm{~mL}$ FC reagent (5-fold diluted with distilled water) and mixed thoroughly for a period of 3 minutes. In addition to that Sodium carbonate $(0.2 \mathrm{~mL}, 10 \% \mathrm{w} / \mathrm{v})$ was put to this mixture, which was left for 30 minutes at room with normal degrees of temperature. The next step was measuring the absorbance of the mixture at $760 \mathrm{~nm}$ using a UV-VIS spectrophotometer V550 model (Jasco, Tokyo, Japan). Finally it was reported that TPC was milligram gallic acid equivalent per_gram defatted L. aromatica ( $m g$ GAE/g DFLA) (McDonald et al., 2001) .

Total flavonoid content: From another side the total flavonoid composition (TFC) of each extract was examined by using the aluminum chloride colorimetry way. To sum up, the extracted sample was lighter with methanol until $100 \mu \mathrm{g} / \mathrm{mL}$. Moreover the calibration curve was presented by a way of lightening quercetin in methanol $(0-100 \mu \mathrm{g} / \mathrm{mL})$. After that the diluted extract or quercetin $(2.0 \mathrm{~mL})$ was put with $0.1 \mathrm{~mL}$ of $10 \%(\mathrm{w} / \mathrm{v})$ aluminum chloride solution and $0.1 \mathrm{~mL}$ of $0.1 \mathrm{~m}$ potassium acetate solution. Then the mixture was necssary to keep it at normal temperature for half an hour. At the end became the measuring of the maximum absorbance of the 
mixture, which found at $415 \mathrm{~nm}$ using a UV-VIS spectrophotometer. TFC was produced as milligram quercetin equivalent per gram defatted $\mathrm{L}$. aromatica ( $m g$ QCE/g DFLA) (Chang et al., 2002).

\section{Biological experiment}

Patient feeding: Tuberculosis patients were given three cups daily $(200 \mathrm{ml})$ for three months of herbal mix or liquid mixture.

Design of biological experiment: All patients were assessed for nutritional status through physical measurements of weight and length clinical examination by doctors, tuberculosis analysis, hemoglobin and hemotecrit ratio. All patients were subjected to the hospital drug and hospital meal beside treatments. Patients were divided into four groups as follows:

- Group 1: Control included 15 patients.

- Group 2: included 15 patients fed on the herbal mixture.

- Group 3: included 15 patients fed on the liquid mixture.

- Group 4: included 15 patients fed on the herbal mixture in addition to the liquid mixture.

\section{Determenation of blood constituents:}

Sample collection: Fasting morning venous blood samples $(5 \mathrm{ml})$ were withdrawn after a 12-14 hours overnight fasting from all sabjects included in the study while they were in the supine position.

Measurement of blood hemoglobin: Blood hemoglobin ( $\mathrm{Hb} \%)$ was performed at central laboratory at Mansoura chest Hospital by using automated blood cell counter (Sysmex,Sysmex corporation Kobe, Japan ) to all patients as recommended by WHO (Bull $\boldsymbol{e t}$ al., 2000) .

Measurement of blood hematocrit: As known hematocrit (PCV) is the measure of the ratio's volume of the red blood cells, comparing to the volume of whole blood. The steps start taking the blood sample into a capillary and centrifugated. After that the ratio can be measured and represented as a decimal or percentage fraction (Bull et al., 2000). 
Tuberculosis analyses: It's known that the skin's tuberculin test,which is reported to discover latent Mycobacterium tuberculosis infection has its flaws. Lately a new diagnostic test for latent tuberculosis (Quanti FERON-TB [QTF-TB]) has been reported. This test is used for measuring the production of IFN- $\gamma$ in all blood,after stimulating using purified protein derivative (PPD). In fact the QTF-TB test addresses the operational mentioned flaws with the skin's tuberculin test. Although the test is based on PPD, it still has a low specificity in populations vaccinated with the Bacile Calmette-Guérin (BCG) vaccine. Furthermore, updated the test in order to include the antigens ESAT-6 and CFP-10, which are not found in BCG vaccine strains or the vast majority of nontuberculous mycobacteria. The final result proved that the majority of the patients were unvaccinated BCG, That led to compare the skin test and the novel blood test directly especially with people, whose skin test was not confounded by vaccination. Finally, a great agreement between the two tests was found $(94 \%, \kappa$ value 0.866$)$. The newer blood test was not influenced by the vaccination status of the subjects tested if it compared to the blood test based on PPD (Harboe, 1981).

Statistical analyses: Recent researches have reported that all analyses were done at least in triplicate. Then these values were presented as average values in parallel with their traditional derivations. By using the minitab software data were discussed. Furthermore it was held some statistical comparisons with one-way analysis of variance, and $\mathrm{p}$ values $<$ 0.05 were regarded as great. In another hand the correlation coefficients (R) between TPC and TFC were calculated in order to define the connection between them (Stalikas, 2007 ).

\section{Results and discussion}

\section{Sensory evaluation of herbal mix and liquid mixture:}

Data concerning the sensory evaluation, texture, oder, taste, color and overall acceptability of herbal mix and the liquid mixture was recorded in table (1). Results showed that herbal mix recorded $6.8 \pm 0.33,7.6 \pm 1.14$, $7.4 \pm 1.16,7.0 \pm 1.58$, and $8.2 \pm 0.83$ for texture, oder, taste, color and overall 
acceptability, respectively. On the other hand, the liquid mixture recorded $7.2 \pm 0.61,6.8 \pm 0.43,6.6 \pm 1.18,7.6 \pm 1.11$ and $7.6 \pm 0.54$, respectively.

Table (1): Sensory evaluation of herbal mix and liquid mixture.

\begin{tabular}{|c|c|c|}
\hline Parameters & Herbal Mix & Liquid mixture \\
\hline Texture & $6.8 \pm 0.33$ & $7.2 \pm 0.61$ \\
\hline Oder & $7.6 \pm 1.14$ & $6.8 \pm 0.43$ \\
\hline Taste & $7.4 \pm 1.16$ & $6.6 \pm 1.18$ \\
\hline Color & $7.0 \pm 1.58$ & $7.6 \pm 1.11$ \\
\hline Overall acceptability & $8.2 \pm 0.83$ & $7.6 \pm 0.54$ \\
\hline
\end{tabular}

Each value in the table is the mean \pm standard deviation of three replicate.

It could be observed from these results that liquid mixture recorded the highest score in texture and color. Herbal mix recorded the highest score in oder, taste and overall acceptability. These results are in harmony with (Serhana et al., 2010) who mentioned that goat's milk is light, sweet, clean and has strong odour and fresh tasting. Peanut is good acceptability for the consumers in colour and flavor (Yanai et al., 2015). Honeysuckle derives its name from the edible sweet nectar obtainable from its tubular flowers (Kula et al., 2016). Juniper is normally fleshy, sweet and edible in the raw states (Mauseth, 2003). Echinacea colors that range from white, pink magenta and purple to yellow(Livesey et al., 1998). Use of fenugreek, is limited by its bitter taste and strong flavor, abread incorporating fenugreek using a proprietary process was tested for its taste acceptability and its effect on carbohydrate metabolism. It seedpods contain ten to twenty small, flat, yellow-brown, pungent and aromatic seeds (Gong et al., 2016).

\section{Chemical composition of herbal mix and liquid mixture:}

Data concerning the chemical composition, moisture, total fat, protein, ash and fiber of herbal mix and liquid mixture was recorded in Table 2. Results showed that herbal mix recorded $9 \pm 0.70,9 \pm 0.70$, $11.44 \pm 0.72,6.33 \pm 0.67$ and $19.62 \pm 1.19 \mathrm{~g} / 100 \mathrm{~g}$ wet weight for moisture, total fat, protein, ash and fiber, respectively. On the other hand, liquid 
mixture recorded $7.04 \pm 0.66,11.11 \pm 1.02,8.36 \pm 0.70,2.05 \pm 0.78$ and $2.71 \pm 0.44 \mathrm{~g} / 100 \mathrm{~g}$ weight for moisture, total fat, protein, ash and fiber, respectively.

Table (2): Chemical composition of herbal mix and liquid mixture.

\begin{tabular}{|c|c|c|}
\hline $\begin{array}{l}\text { Parameter } \\
\text { Sample }\end{array}$ & Herbal mix & liquid mixture \\
\hline Moisture (g/100g) & $9 \pm 0.70$ & $7.04 \pm 0.66$ \\
\hline Total fat $(\mathrm{g} / 100)$ & $9 \pm 0.70$ & $11.11 \pm 1.02$ \\
\hline $\operatorname{Protein}(\mathrm{g} / 100 \mathrm{~g})$ & $11.44 \pm 0.72$ & $8.36 \pm 0.70$ \\
\hline Ash $(g / 100)$ & $6.33 \pm 0.67$ & $2.05 \pm 0.78$ \\
\hline Fiber $(\mathrm{g} / 100)$ & $19.62 \pm 1.19$ & $2.71 \pm 0.44$ \\
\hline
\end{tabular}

Each value in the table is the mean \pm standard deviation of three replicate.

It could be observed from these results that herbal mix is richer in protein, ash and fiber than those of liquid mixture, however liquid mixture was higher in fat content than herbal mix. Results were in harmony with those obtained by (Deineka et al., 2005) who showed that honeysuckle contained $6 \%$ protein, $34 \%$ crude fiber, $8 \%$ crude ash, $11 \%$ moisture, $6 \%$ lipid and 3\% fat. Horehound contain: 5\% calories, $2 \%$ total carbohydrates, 4\% fiber, $2 \%$ protein and 2\% total carbohydrates (Bokaeian et al., 2014). Echinacea contained $15 \%$ protein, $4 \%$ fat, $5.26 \%$ fiber, $3.12 \%$ ash and $72 \%$ carbohydrates (Nusslein et al., 2000). Chemical composition of fenugreek: (28.55\% protein, $4.00 \%$ fat, $6.50 \%$ fiber, $3.20 \%$ ash, $4.00 \%$ moisture and $46.25 \%$ carbohydrates) (Losso et al., 2009). Chemical composition and nutritive value of goat's milk constituents including 2.83, 3.06\% fat and 3.28, 3.41\% protein (Marques et al., 2003). Honey is a sticky and viscous solution with a content of $80-85 \%$ carbohydrate (mainly glucose and fructose), $15-17 \%$ water, $0.1-0.4 \%$ protein and $0.2 \%$ ash (Ajanaku, 2009). Peanuts contain high percentages of oil (45-54\%) and protein (25-31\%) (Frankel, 2005). 


\section{Total phenols and flavonoids of herbal mix:}

Data concerning the total phenols and flavonoids of herbal mix was recorded in Table 3. Results show that total phenols of herbal mix recorded $13.62 \pm 0.96 \mathrm{~g} / 100 \mathrm{~g}$, while it recorded $6.85 \pm 0.85 \mathrm{~g} / 100 \mathrm{~g}$ for flavonoids.

Table (3): Total phenols and flavonoids of herbal mix.

\begin{tabular}{|l|l|}
\hline Parameter & Herbal mix \\
\hline \hline Total phenols $(\mathrm{g} / 100 \mathrm{~g})$ & $13.62 \pm 0.96$ \\
\hline Flavonoids $(\mathrm{g} / 100 \mathrm{~g})$ & $6.85 \pm 0.85$ \\
\hline
\end{tabular}

Each value in the table is the mean \pm standard deviation of three replicate

It could be observed be from these results that herbal mix is rich in phenols and flavonoids. Results were in harmony with those obtained by (Deineka et al., 2005) who showed that honeysuckle contained the presence of 5-12 phenolic compounds in relation to species, honeysuckle have a high content of anthocyanins $1.40 \mathrm{mg} / 100 \mathrm{~g}$, phenolic acids $160 \mathrm{mg} / 100 \mathrm{~g}$ and flavonoids $140 \mathrm{mg} / 100 \mathrm{~g}$. The honeysuckle contain the phenolic fraction $0.40 \%, 0.9 \%$ (flavonoids), and $0.7 \%$ (phenolic acids). (Jeong et al., 2005) Echinacea contains at least six distinct chemical constituents with pharmacologic activity (polysaccharides, flavonoids, chicoric acid glycosides, essential oils, polyacetylenes, and alkylamides) (Kim et al., 2000).

\section{Weight and Body Mass Index:}

Regarding weight level; It could be noticed that weight level increased in the (TB) patient's blood (control group) after three months of feeding on the hospital diet side by side subject to treatment by $(5 \mathrm{~kg})$ comparing to its level at the beganing of hospitalization. Meanwhile, treated TB patients fed on the herbal mix in addition to the hospital diet caused increasing in weight level at the end of experiment period by $(6.2 \mathrm{~kg})$ as shown in group 2. In the same times feeding treated TB patients on liquid mixture in addition to the hospital diet increased the weight. level by $(8.64$ $\mathrm{kg}$ ) as shown in group 3. Feeding treated TB patients on the hospital diet beside herbal mix side by side liquid mixture increased weight level to ( 8.74 
$\mathrm{kg}$ ) as recorded in group 4. An obivious elevating was observed in weight levels occurred by feeding treated TB patients on hospital diet beside herbal mix or liquid mixture especially, feeding on the twice together.

Regarding body mass index level; It could be noticed that BMI level increased in the TB patient's blood (control group) after three months of feeding on the hospital diet side by side subject to treatment by (2.92) comparing to its level at the beganing of hospitalization. Meanwhile, treated TB patients fed on the herbal mix in addition to the hospital diet caused increasing in BMI level at the end of experiment period by (3.81) as shown in group 2. In the same times feeding treated TB patients on liquid mixture in addition to the hospital diet increased BMI level by (6.12) as shown in group 3. Feeding treated TB patients on the herbal mix side by side liquid mixture increased BMI level to (6.86) as recorded in group 4. An obivious elevating was observed in weight levels occurred by feeding treated TB patients on hospital diet beside herbal mix or liquid mixture especially, feeding on the twice together.

Table(4): Weight and Body Mass Index for studied subjects between groups.

\begin{tabular}{|c|c|c|c|c|c|}
\hline \multirow{2}{*}{\multicolumn{2}{|c|}{ ||lParameters }} & G1-Control & Group (2) & Group (3) & Group (4) \\
\hline & & $\mathrm{M} \pm \mathrm{SD}$ & $\mathrm{M} \pm \mathrm{SD}$ & $\mathrm{M} \pm \mathrm{SD}$ & $\mathrm{M} \pm \mathrm{SD}$ \\
\hline \multirow{4}{*}{ Weight $(\mathrm{kg})$} & Zero time & $60 \pm 1.02 \mathrm{a}$ & $60.26 \pm 4.71 \mathrm{a}^{*}$ & $59.06 \pm 2.36 \mathrm{a}^{* *}$ & $59.76 \pm 2.73 \mathrm{a}^{* *}$ \\
\hline & (1) month & $61.6 \pm 4.33 \mathrm{~b}$ & $62 \pm 1.73 b^{*}$ & $64.6 \pm 3.27 \mathrm{a}^{*}$ & $64.83 \pm 5.82 \mathrm{a}^{*}$ \\
\hline & (2) month & $63.2 \pm 6.11 \mathrm{~b}$ & $64 \pm 4.87 \mathrm{~b}^{*}$ & $66.73 \pm 3.38 \mathrm{a}$ & $66.4 \pm 3.66 \mathrm{a}$ \\
\hline & (3) month & $65 \pm 6.54 b$ & $66.46 \pm 5.07 b^{*}$ & $67.7 \pm 6.26 \mathrm{a}^{* *}$ & $68.5 \pm 5.63 \mathrm{a}^{* *}$ \\
\hline \multicolumn{2}{|c|}{ Height $(\mathrm{cm})$} & $164.8 \pm 4.87 \mathrm{a}$ & $164.2 \pm 1.74 \mathrm{a}$ & $163.67 \pm 7.12 b$ & $165.07 \pm 7.8 \mathrm{a}$ \\
\hline \multirow{4}{*}{$\begin{array}{c}\text { Body Mass } \\
\text { Index }(\mathrm{kg} / \mathrm{m} 2)\end{array}$} & Zero time & $22.82 \pm 3.4 \mathrm{a}$ & $22.76 \pm 3.31 \mathrm{a}$ & $21.18 \pm 2.99 \mathrm{~b} * *$ & $21.77 \pm 4.4 \mathrm{a}$ \\
\hline & (1) month & $23.45 \pm 3.52 b$ & $23.93 \pm 3.38 b$ & $24.37 \pm 3.09 \mathrm{a}^{*}$ & $25.17 \pm 4.45 \mathrm{a}$ \\
\hline & (2) month & $24.28 \pm 3.55 b$ & $24.53 \pm 4.03 b$ & $25.52 \pm 2.87 \mathrm{a}$ & $25.97 \pm 4.16 \mathrm{a}^{*}$ \\
\hline & (3) month & $25.74 \pm 3.56 b$ & $26.57 \pm 4.19 b$ & $27.3 \pm 2.95 \mathrm{a}$ & $28.53 \pm 4.36 \mathrm{a}^{* *}$ \\
\hline
\end{tabular}

${ }^{*} \mathrm{p}<0.05$ significant $* * \mathrm{p}<0.01$ high significant $* * * \mathrm{p}<0.001$ very high significant.

Mean values in each column having different superscript (a, b, c, d) are significant. 
Finnally, it could be observed from these results that TB patients who feed on the herbal mix and liquid mixture achieved the highest results in weight and BMI as shown in the fourth group. Meanwhile, weight levels of TB patients fed on the liquid mixture were higher than patients weight which fed on the herbal mix. Results were in harmony with those obtained by (Davis et al., 2006). Fenogreek contains saponins, which help improve digestion and improve digestive enzymes. which promote weight gain (Hannan et al., 2007). Fenogreek properties come from its ability to improve food absorption and increase appetite. In addition, gentian also promotes better gastric secretion and enzyme absorption (Grover et al., 2002).

\section{Hemoglobein and hematocrit:}

Regarding hemoglobin level; It could be noticed that hemoglobin level increased in the tuberculosis (TB) patients blood (control group) after three months of feeding on the hospital diet in addition to hospital treatment by $(2.0 \mathrm{~g} / \mathrm{dl})$ comparing to its level at the beganing of hospitalization. Meanwhile, treated TB patients fed on the herbal mix in addition to the hospital diet caused increasing in hemoglobin level at the end of experiment period by $(2.3 \mathrm{~g} / d l)$ as shown in group 2. In the same time feeding treated TB patients on liquid mixture in addition to the hospital diet increased the hemoglobin level by $(4.0 \mathrm{~g} / \mathrm{dl})$ as shown in group 3 . Feeding treated TB patients on the herbal mix side by side to liquid mixture increased hemoglobin level to $(4.1 \mathrm{~g} / d l)$ as recorded in group 4. An obivious elevating was observed in hemoglobin levels occurred by feeding treated TB patients on herbal mix or liquid mixture especially, feeding on the twice together.

Regarding hematocrit level; It could be noticed that hematocrit level increased in the TB patient's blood (control group) after three months of feeding on the hospital diet side by side subject to treatment by $(5.26 \%)$ comparing to its level at the beganing of hospitalization as shown in the control group. Meanwhile, treated TB patients fed on the herbal mix is addition to the hospital diet caused increasing in hematocrit level at the end of experiment period by $(4.91 \%)$ as shown in group 2 . In the same times 
feeding treated TB patients on liquid mixture in addition to the hospital diet increased the hematocrit level by $(7.04 \%)$ as shown in group 3 . Feeding treated TB patients on the herbal mix side by side to liquid mixture increased hematocrit level to $(7.39 \%)$ as recorded in group 4. An obivious elevating was observed in hematocrit levels occurred by feeding treated TB patients on herbal mix or liquid mixture especially, feeding on the twice together.

Table (5): Hemoglobein and hematocrit levels in tuberculosis patient's blood:

\begin{tabular}{|c|c|c|c|c|c|}
\hline & G1 (Control) & Group (2) & Group (3) & Group (3) \\
\hline & & $\mathrm{M} \pm \mathrm{SD}$ & $\mathrm{M} \pm \mathrm{SD}$ & $\mathrm{M} \pm \mathrm{SD}$ & $\mathrm{M} \pm \mathrm{SD}$ \\
\hline \multirow{4}{*}{$\begin{array}{c}\text { Hemoglobein } \\
\mathrm{g} / \mathrm{dl})(\end{array}$} & Zero time & $11.8 \pm 0.41 \mathrm{a}$ & $12.4 \pm 0.5 \mathrm{a}^{* * *}$ & $12 \pm 0.1 \mathrm{a}^{*}$ & $12.3 \pm 0.1 \mathrm{a}^{*}$ \\
\hline & (1) month & $12.8 \pm 0.22 \mathrm{~b}$ & $13.33 \pm 0.48 \mathrm{~b}^{* *}$ & $14 \pm 0.1 \mathrm{a} * * *$ & $14.5 \pm 0.1 \mathrm{a}^{* * *}$ \\
\hline & (2) month & $13.6 \pm 0.51 \mathrm{~b}$ & $14 \pm 0.37 b^{*}$ & $15 \pm 0.1 \mathrm{a}^{* * *}$ & $15.3 \pm 0.1 \mathrm{a}^{* * *}$ \\
\hline & (3) month & $13.8 \pm 0.11 \mathrm{~b}$ & $14.7 \pm 0.01 \mathrm{~b}$ & $16 \pm 0.9 a^{* * *}$ & $16.4 \pm 0.9 \mathrm{a}^{* * *}$ \\
\hline \multirow{4}{*}{$\begin{array}{c}\text { Hematocrit } \\
(\%)\end{array}$} & Zero time & $36.54 \pm 0.1 \mathrm{a}$ & $37.36 \pm 0.45 \mathrm{a}^{* *}$ & $37 \pm 0.1 \mathrm{a}$ & $37.24 . \pm 0.1 \mathrm{a}$ \\
\hline & (1) month & $38 \pm 0.65 b$ & $39.87 \pm 0.83 b$ & $41 \pm 0.1 \mathrm{a}^{* * *}$ & $41.15 \pm 0.1 \mathrm{a}^{* * *}$ \\
\hline & (2) month & $40 \pm 1.3 b$ & $41 \pm 0.92 b^{* *}$ & $43 . \pm 0.1 \mathrm{a}^{* * *}$ & $43.22 \pm 0.1 \mathrm{a}^{* * *}$ \\
\hline & (3) month & $41.8 \pm 1.05 \mathrm{~b}$ & $42.27 \pm 0.88 b$ & $44.04 \pm 1.58 \mathrm{a} * * *$ & $44.63 \pm 1.58 \mathrm{a}^{* * *}$ \\
\hline
\end{tabular}

${ }^{*} \mathrm{p}<0.05$ significant $* * \mathrm{p}<0.01$ high significant $* * * \mathrm{p}<0.001$ very high significant

Mean values in each column having different superscript (a, b, c, d) are significant.

Finnally, it could be observed from these results that TB patients who feed on the herbal mix and liquid mixture achieved the highest results in hemoglobein and hematocrit as shown in the fourth group. Meanwhile, hemoglobein blood levels of TB patients fed on the liquid mixture were higher than patients hemoglobein which fed on the herbal mix. These results may be due to the high iron and minerals contents of liquid mixture and herbal mix components. The daily use of fenugreek seeds as dietary supplement has good beneficial effects to raise blood hemoglobin by easy means. This might further help to prevent and cure anemia and maintain good healthy life for longer duration (Gong et al., 2016). Honey is very 
good for the entire body. It contains a good amount of iron. You will get about $0.42 \mathrm{mg}$ of iron in 100 grams of honey, it contains copper and magnesium that will help in increasing the hemoglobin in your body (Ozer, 2000). Echinacea supplementation $(1000 \mathrm{mg} / \mathrm{d}$ for $42 \mathrm{~d})$ resulted in an increase in the number and size of red blood cells (RBCs), hemoglobin (Hb), and hematocrit (HCT) (Goel et al., 2002). Goat's milk also had a greater iron bioavailability in anemic rats, anemic rats fed on goat's milk grew significantly better, had higher liver weights and hemoglobin regeneration efficiency (Cutic et al., 2004).

*Table (6): Tuberculosis bacteria level in patient's sputum samples:

\begin{tabular}{|c||c|c|c|c|}
\hline groups & Zero & $\begin{array}{c}\text { (one } \\
\text { month) }\end{array}$ & (two month) & (three month) \\
\hline \hline (g 1) Control & $(+++)$ & $(+++)$ & $(++)$ & $(+)$ \\
\hline group 2 & $(+++)$ & $(+)$ & $(-)$ & $(-)$ \\
\hline group 3 & $(+++)$ & $(++)$ & $(+)$ & $(-)$ \\
\hline group 4 & $(+++)$ & $(+)$ & $(-)$ & $(-)$ \\
\hline
\end{tabular}

\section{Analysis of the level of TB bacteria in spitting TB patients:}

At the beginning of hospitalization, no differences were noticed between all tuberculosis bacteria (TB) patients as all groups recorded $(+++)$. After the first month, the laboratony tests confirmed that the number of TB still $(+++)$ in the control group depending on the hospital drugs. In the same time, TB patients fed on the herbal mix as well as the hospital drugs (group 2) recorded a decrease in the TB level to $(+)$ compared to its level at the beginning of hospitalization. In the same time, feeding TB patients on liquid mixture beside hospital drug (group 3) reduced the level of TB to level (++). Meanwhile, feeding TB patients treated on the herbal mix and liquid mixture together beside the hospital drug (group 4) decreased the level of TB to $(+)$.

After the second month, there was a decrease in the number of TB bacteria in the control group to $(++)$. Regarding tuberculosis bacteria in (group 2), feeding patients on herbal mix only or herbal mix and liquid 
mixture together (group 4) beside hospital drugs, completely eliminated tuberculosis in patients. However, feeding TB patients on liquid mixture beside hospital drugs (group 4) decreased tuberculosis bacteria to $(+)$ in compring with the control groups.

At the end of the experiment after the third month, laboratony tests confirmed that groups (2,3 and 4) were completely eradicated tuberculosis bacteria causing the disease, while the control group was still suffering from the presence of bacteria causing tuberculosis. An obivious decrease in TB levels was observed by feeding TB patients on herb mix and liquid mixture together beside the hospital drugs.

Finnally, it could be observed from these results that patients suffening from $\mathrm{TB}$ and subjected to hospital drug side by side our treatmentas represented in groups 2,3 and 4 achieved rapid healing compring to the control group which contain TB patients subjected to hospital drugs only.

Feeding TB patients beside hospital drugs on herbal mix and liquid mixture together, also feeding on herbal mix only achieved the highest results in tuberculosis bacteria elimination followed by TB patients group fed on liquid mixture only as compared to control group.

There are numerous pharmacological effects honeysuckle. It helped cure colds, fever, inflammation, swelling, boils, sores, and viral and bacterial infections. Today, this honeysuckle is a proven antibiotic. It is a broad spectrum antibiotic for bacteria such as staphylococcus aureus, mycobacterium tuberculosis. Most of these bacteria cause serious illness in humans that can result in death (Jin et al., 2006).

Horehound used for the treatment of inflammatory-related symptoms such as cold, fever, and sore throat. M. vulgare is also used for respiratory problems such as asthma and cough (Yousefi et al., 2013). The use of juniper has been approved for dyspepsia and, with other plants for bladder and kidney conditions. juniper has digestive, stomachic, and antirheumatic properties, because of these antiseptic properties investigate the antimicrobial activity of the essential juniper against some bacterial 
(Angionl et al., 2003). Echinacea modulate immune system function to alleviate the severity and duration of colds and flu (Perry et al., 2000). The use of goat's milk substitute in human diets has been reported in much anecdotal literature about persons who suffer from eczema, asthma, chronic catarrh, migraine, colitis, hayfever, stomach ulcer, epigastric distress, and abdominal pain due to allergenicity of cow's milk protein (Moreno et al., 2005). Therapy honey used for wound healing, laxative action, cough and sore throat, topical antisepsis, prevention and treatment (Asadi-Pooya, 2003).

\section{References}

- Ajanaku, K O (2009): Physical characteristics of some honey samples from North-Central Nigeria. International Journal of Physical Sciences 4: 464 -470.

- Angelis, M; Siragusa, S; Berloco, M; Caputo, L; Settanni, L; Alfonsi, G; Amerio, M; Grandi, A; Ragni, A and Gobbetti, M (2006): Selection of potential probiotic lactobacilli from pig feces to be used as additives in pelleted feeling. Res. Microbio. 157, 792-801.

- Angionl, A; Barra, A; Russo, M T; Coroneo, V; Dessl, S and Cabras, P (2003): Chemical composition of the essential oils of Juniperus from ripe and unripe berries and leaves and their antimicrobial activity, Journal Agric. Food Chem., 51, 3073-3078.

- Asadi-Pooya, A A (2003): Pnjehihahin MR and BeheshtiS. Theantimycobacterial effect of honey : an in vitro study. Biology Forum 96:4916.

- Basch, E; Ulbricht, C; Kuo, G; Szapary, P and Smith, M (2003): Therapeutic applications of fenugreek. Altern. Med. Rev. 8, 20-27.

- Bokaeian, M; Saboori, E; Saeidi, S; Niazi, A A; Amini, N and Khaje, H (2014): Phytochemical analysis, antibacterial activity of (Marrubium vulgare L) against Staphylococcus aureus in vitro. Zahedan J Res Med Sci .16:60-4.

- Bull, B S; Koepke, J A and Simson, E (2000): Procedure for determining packed cell volume by the hematocrit method. Third edition. NCCLS publication H7-A3. Wayne, Pennsylvania: NCCLS. 
- Cai, H; Shu, X O; Hebert, J R; Jin, F; Yang, G and Liu, D K (2004): Variation in nutrient intakes among women in Shanghai, China. Eur J Clin Nutr 58:1604-1611. [PubMed: 15199383.

- Chang, C C; Yang, M H and Wen, H M (2002): Estimation of total flavonoid content in propolis by two complementary colorimetric methods. J Food Drug Anal. 10: 178-182

- Chen, L; Mehta, A; Berenbaum, M; Zangerl, A R and Engeseth, N J (2000): Honeys from different floral sources as inhibitors of enzymatic browning in fruit and vegetable homogenates . J Agric Food Chem. 48:4997-5000.

- Cutic, V; Hardi, J; Slacanac, V; Pavlovic, H and Vukovic, D (2004): Inhibitory effect of goat and cow milk fermented by ABT-2 culture (Lactobacillus acidophilus La-5, Bifidobacteriumlactis Bb-12 and Streptococcus thermophilus) on the growth of some uropathogenic E. coli strains. Ital. J. Food Sci. 16, 209-220.

- Davis, J N; Hodges, V A and Gillham, M B ( 2006): Normal-weight adults consume more fiber and fruit than their age and heightmatched overweight/obese counterparts. J Am Diet Assoc 106: 833-840.

- Deineka, V I; Sorokopudov, V N; Deineka, L A; Shaposhnik, E I and Koltsov, S V (2005): Anthocyans from fruit of some plants of the Caprifoliaceae family. Chem. Nat. Compd. 41, 162-164.

- Diehl, M (1991). Productivity loss in idea-generating groups: Tracking down the blocking effect. Journal of Personality and Social Psychology, 61(3), 392-403.

- Diehl, M (2003): AM.Oxidative stress and oval cell accumulation in mice and humans with alcoholic and nonalcoholic fatty liver disease. Am $J$ Pathol. 163:1301-11.

- Frankel, E N (2005): Lipid Oxidation, 2nd Ed., 1-470. The Oily Press. Bridgewater, England. Grosso NR, Guzman CA. 1995. Chemical composition of aboriginal peanut (A. hypogaea) seeds from Peru. J Agric Food Chem. 43, 102105.

- Goel, V C; Chang, J V and Slama, h (2002): Alkylamides of Echinacea purpurea stimulate alveolar macrophage function in normal rats. Int. Immunopharmacol. 2:381-387, 
- Gong, J; Fang, K; Dong, H; Wang, D; Hu, M and Lu, F (2016): "Effect of Fenugreek on Hyperglycaemia and Hyperlipidemia in Diabetes and Prediabetes: a Meta-analysis". Journal of Ethnopharmacology. 194: PMID27496582 268. doi:10.1016/j.jep.2016.08.003.

- Grover, J K; Yadav, S and Vats, V ( 2002): Medicinal plants of India with diabetic potential. Journal Ethnopharmacology 81: 81-100.

- Halezeroğlu, S and Okur, E (2014): "Thoracic surgery for haemoptysis in the context of tuberculosis: what is the best management approach?". Journal of Thoracic Disease. 6 (3): 182-5. doi:10.3978/j.issn.2072-1439.2013.12.25. PMC 3949181 $\square$. PMID 24624281.

- Hannan, J M A; Ali, L; Rokeya, B; Khaleque, J; Akhter, M; Flatt, P R and Abdel-Wahab, Y H A (2007): Soluble dietary fibre fraction of Trigonella foenum-graecum (fenugreek) seed improves glucose homeostasis in animal models of type 1 and type 2 diabetes by delaying carbohydrate digestion and absorption, and enhancing insulin action. Br J Nutr 97: 514-521.

- Harboe, M (1981): Antigens of PPD, old tuberculin, and autoclaved Mycobacterium bovis BCG studied by crossed immunoelectrophoresis. Am Rev Respir Dis .124:80-87.

- Hossain, S; Larson, C P; Quaiyum, M A; Khan, A I and Zaman, K (2010): Adults with chronic cough in urban Bangladesh: healthcare utilization and management of cases by private practitioners. World Health \& Population 12: 517.

- Jeong, Y J; Choi, Y J; Kwon, H M; Kang, S W; Park, H S;Lee, M and Kang, Y H (2005): Differential inhibition of oxidized LDL-induced apoptosis in human endothelial cells treated with different flavonoids. J. Nutr. 93, 581-591.

- Jin, X H; Ohgami, K; Shiratori, K; Suzuki, Y; Koyama, Y; Yoshida, K; Ilieva, I; Tanaka, T; Onoe, $K$ and Ohno, $S$ (2006): Effects of blue honeysuckle (Lonicera caerulea L.) extract on lipopolysaccharide-induced inflammation in vitro and in vivo. Exp. Eye Res. 82:860-867. doi: 10.1016/j.exer.2005.10.024.

- Jin, X H; Ohgami, K; Shiratori, K; Suzui, Y; Koyama, Y; Yoshida, k; Ilieva, T; Tanaka, T; Onoe, $\mathbf{K}$ and Ohno $\mathbf{S}$ (2006): Effects of blue honeysuckle 
(Lonicera caerulea L.) extract on lipopolysaccharide-induced infla m- mation in vitro and in vivo. EXP. EYE RES. 82(5) : 860-867.

- Kim, H O; Durance, T D; Scaman, C H and Kitts, D D (2000): Retention of caffeic acid derivatives in dried (Echinacea purpurea) , J. Agric. Food Chem., 48: 4182-4186.

- Konstantinos, A (2010): "Testing for tuberculosis". Australian Prescriber. 33 (1): $12-18$.

- Kula, M; Glód, D; Krauze and Baranowska, M (2016): "Application of online and off-line heart-cutting LC in determination of secondary metabolites from the flowers of Lonicera caeruleacultivar varieties". Journal of Pharmaceutical and BiomedicalAnalysis. 131:326. doi:10.1016/j.jpba.2016.09.010. PMID 27622313.: 316.

- Livesey, J C; Bergeron, J; Rana, D V C; Awang, W; Letchamo and Arnason (1998): Developing of a method for identity assurance and quality control in Echinacea spp. Paper presented at the conference of the American Society of Pharmacognosy, Orlando, Florida, July 1998.

- Losso, J N; Holliday, D L; Finley, J W; Martin, R J; Rood, J C; Yu, Y and Greenway, F L (2009): Fenugreek bread: A treatment for diabetes mellitus. $J$. Med. Food. 12:1046-1049. doi: 10.1089/jmf.2008.0199.

- Marques, P X; Pereira, M; Marques, M R; Santos, I C; Belo, C C; Renaville, $\mathbf{R}$ and Cravador, A (2003): Association of milk traits with SSCP polymorphisms at the growth hor- mone gene in the Serrana goat. Small Ruminant Research50177-185.

- Mauseth, J D (2003): Botany, an Introduction to Plant Biology. Boston, Jomes and barlet Publishers. p. 285.

- McDonald, S; Prenzler, P D and Antolovich, M (2001): Phenolic content and antioxidant activity of olive extracts. Food Chem. 73: 73-84.

- Moreno de LeBlanc, A; Matara, C; Theriaulta, C and Perdigon, G ( 2005): Effects of milk fermented by Lactobacillus helveticus R389 on immune cells associated to mammary glands in normal and a breast cancer model. Immunobiology 210, 349-35. 
- Nusslein, B; Kurzmann, M; Bauer, R and Kreis, W (2000): Enzy matic degradation of cichoric acid in Echinacea purpurea preparations, J. Nat. Prod., 63: 1615-1618.

- Ozer, H (2000): update of recommendations for the use of hematopoietic colony-stimulating factors: evidencebased, clinical practice guidelines. $J$ Clin Oncol .18. 3558-3585.

- Perry, N B; Klink, J W; Burgess, E J and Parmenter, G A ( 2000): Alkamide levels in Echinacea purpurea: effects of processing, drying and storage, Planta Med., 66: 54-6.

- Perry, N B; Anderson, R; Burgess, E J; Follett, J M; Martin, D and Smallfield, B M (2002): Echinacea purpurea: Variation in Yield and Quality between Plant Parts, Harvest D ates and Sites, Crop and Food Research, New Zealand.

- Pukalskas, A; Venskutonis, P R; Salido, S; Waard, P and Beek, T A (2012): Isolation, identification and activity of natural antioxidants from horehound (Marrubium vulgare L) cultivated in Lithuania. Food Chem 130:695-701.

- Serhana, M; Lindera, M; Hosrib, C and Fannia, J (2010): Changes in proteolysis and volatile fraction during ripening of Darfiyeh, a Lebanese artisanal raw goat's milk cheese. Small Rumin Res90:75-82)

- Stalikas, C D (2007): Extraction, separation, and detection methods for phenolic acids and flavonoids. J Sci. 30: 3268-3295 .

- Sugimoto, N; Sato, K; Yamazaki, T and Tanamoto, K (2004): Analysis of absinthin in absinth extract bittering agent. Japanese Journal of Food Chemistry, 11(2), 86-90.

- Wursch, P; Del Vedovo, S; Rosset, J and Smiley, M (1984): The tannin granules from ripe carob pod.

- Yanai, H; Katsuyama, H; Hamasaki, H; Abe, S;Tada, N and Sako, A (2015):"Effects of Dietary Fat Intake on HDL Metabolism". J Clin Med Res. 7 (3): doi:10.14740/jocmr2030w. PMC 4285059. PMID 25584098.

- Yousefi, K; Soraya, H; Fathiazad, F; Khorrami, A; Hamedeyazdan, S and Maleki-Dizaji, N (2013): Cardioprotective effect of methanolic extract of (Marrubium vulgare L). on isoproterenol-induced acute myocardial infarction in rats. Indian J Exp Biol .51:653-60. 


\section{تقييم التأثير العلاجى لبعض الأعشاب والأطعمة على هرضى الدرن}

اعداد

فاطمةتمحمد محمد الشكيتخ

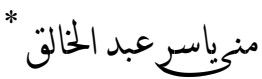

أشرف رفعت محمد الزينحـــ

u|l|

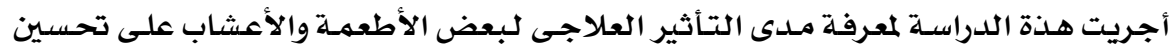

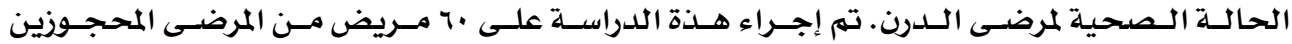

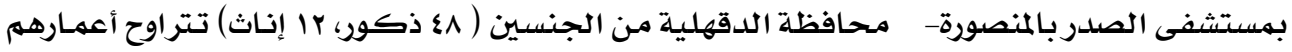

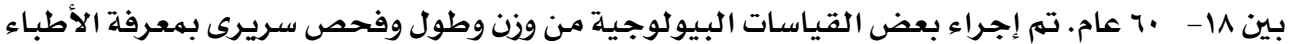

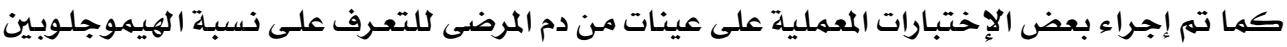

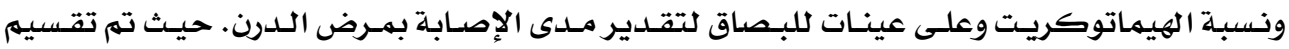

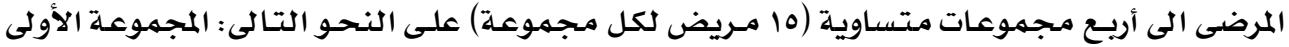

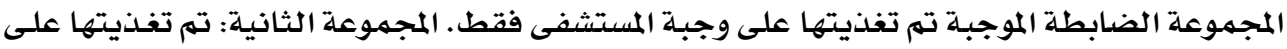

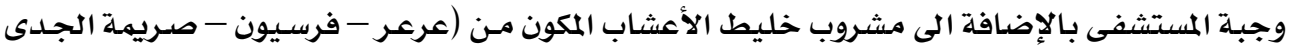

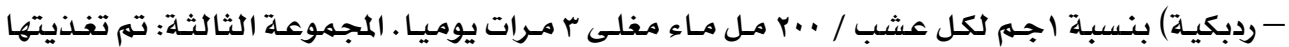

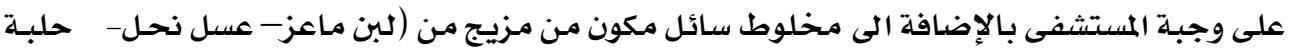

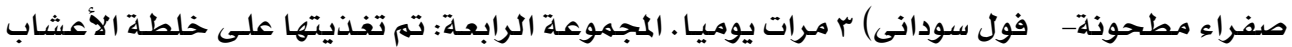

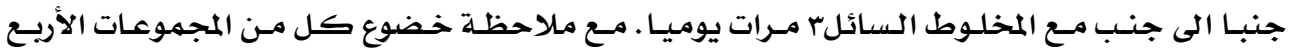

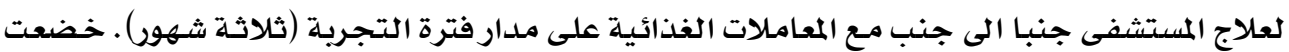

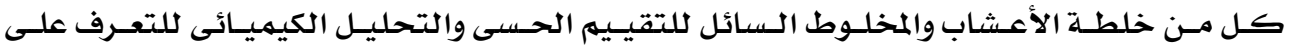

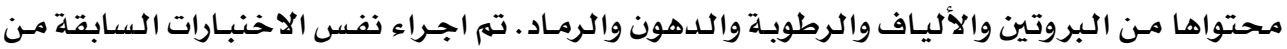

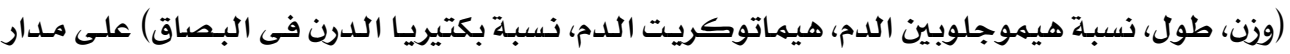

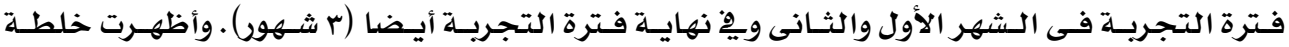

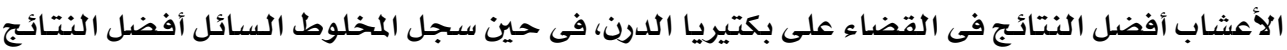

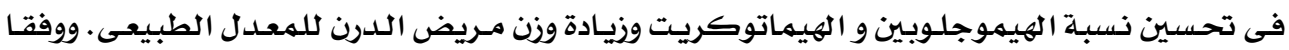

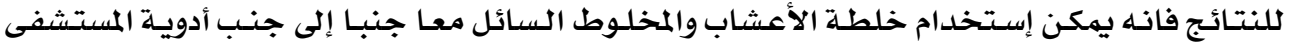

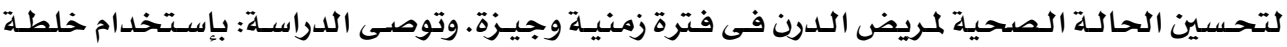

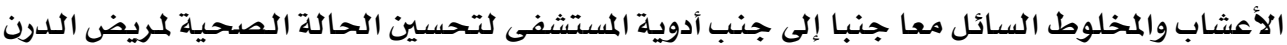
فى وقت قصير ·

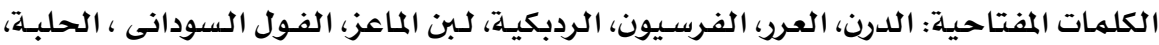

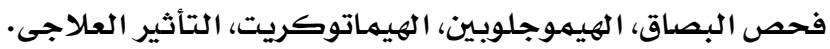

قسم الاقتصادالمنزلى - كلية التربية النوعية - جامعة المنصورة - مصر 